\title{
1: $222383571-222380718$
}

National Cancer Institute

\section{Source}

National Cancer Institute. 1:222383571-222380718. NCI Thesaurus. Code C44977.

Physical location of LEFTB_Gene 